\title{
Utilization of flower waste for nutrient rich compost generation through decomposition
}

\author{
P. N. Gaikwad», S. J. Gahukar*, D. R. Rathod, B. S. Taynath, R. S. Chavan**, A. H. Tupke**, A. R. Zadokar**, P. M. Raut and \\ S. J. Kharade \\ Centre of Excellence in Plant Biotechnology, Dr. Panjabrao Deshmukh Krishi Vidyapeeth, Akola-444104, Maharashtra, India \\ *College of Food Technology, Yavatmal, Dr. Panjabrao Deshmukh Krishi Vidyapeeth, Akola-444104, Maharashtra, India \\ **Seed Technology and Research Unit, Dr. Panjabrao Deshmukh Krishi Vidyapeeth, Akola-444104, Maharashtra, India
}

\section{Article Info}

Article history

Received 11 March 2021

Revised 28 April 2021

Accepted 29 April 2021

Published online 30 June 2021

Keywords

Flower waste

Composting

Agitated pit

Nutrients

Organic matter

\begin{abstract}
Major environmental problems are because of dumping all flower waste in the land fills and revers by its more degradable nature. However, by using the flower waste as a raw material for higher nutrient rich compost generated within minimum cost of production. Therefore, this present investigation was evaluated by using pit composting of collected flower waste with various combination of the saw dust and cow dung to yield stabilized compost. Rectangular shaped five agitated pits were formed for different flower waste composting. $50 \mathrm{~kg}$ of flower waste in $\mathrm{Pit}\left(\mathrm{P}_{0}\right)$ was used as control for present study. The mixture of the flower waste quantity with cow dung and saw dust in all other pits was $50 \mathrm{~kg}$, viz., $\mathrm{P}_{1}(25: 20: 5) \mathrm{kg}, \mathrm{P}_{2}(30: 15: 5) \mathrm{kg}, \mathrm{P}_{3}(35: 10: 5) \mathrm{kg}, \mathrm{P}_{4}(40: 5: 5) \mathrm{kg}$, respectively. The highest temperature was recorded in $\mathrm{P}_{0}$ pit between the ranges of 50 to $60^{\circ} \mathrm{C}$ for the first ten days of composting. The compost was stabilized at appropriate mixture of flower waste, saw dust and the cow dung which shows the exact physicochemical characteristics of prepared compost. The $\mathrm{pH}$ of the pit $\mathrm{P}_{2}$ was recorded 7.3 and the $3.7 \mathrm{mS} \mathrm{cm}^{-1}$ electrical conductivity was observed. $33 \%$ total organic carbon, 2.1 $\%$ total nitrogen and $13 \mathrm{C}: \mathrm{N}$ ratio was recorded in the same pit and finally among the entire pit, this proportion is good. For the stabilized flower waste compost, the appropriate flower waste proportion works a prime role in the microbial transformation for providing essential conditions to the compost it works efficiently. Growth of the microbes influenced by the temperature and for fastest degradation of organic waste, the maximum temperature was essential. Cow dung and saw dust which were in combination with flower waste which were successful at the time of pit composting.
\end{abstract}

\section{Introduction}

To control the gradually increasing waste generation by composting the organic waste is effective waste management practices. The flowers are mostly used in temples, churches, and marriages for either worship of God or decoration purpose which ultimately generated large amount of flower waste (Bertran and Sort, 2004). After the use of the flowers which are improperly disposed into the water or dumped on the social places which causes some diseases or environmental problems, viz., water pollution and soil majorly (Dwivedi et al., 2019; Singh et al., 2018). From rural as well as urban places, nearly 50-60 kg of flower waste generated from temples, churches, and marriages approximately which is serious problem regarding environmental pollutions (Yadav et al., 2018).

Due to our Indian religiousness, many peoples strictly avoid throwing the flowers and other materials which are used for at the

\section{Corresponding author: Mr. P.N. Gaikwad}

Centre of Excellence in Plant Biotechnology, Dr. Panjabrao Deshmukh Krishi Vidyapeeth, Akola-444104, Maharashtra, India E-mail: popatgaikwad164@gmail.com

Tel.: +91-9623843121

Copyright (C) 2021 Ukaaz Publications. All rights reserved.

Email: ukaaz@yahoo.com; Website: www.ukaazpublications.com time of prayers and indirectly its garbage that flower waste put in the polythene bags and throw them in water or in the open places (Suraliwala et al., 2017).

These flower materials thrown on open places or in the water which decay aerobically and anaerobically to born foul smell, harmful gases and liquid waste which causes human health problems around the flower waste (Gayatri and Amita, 2016; Kumar et al., 2020). In each year, nearly $80,00,000$ tons of flower wastes are thrown into the Indian rivers. Out of all flower waste, mostly marigold flower is abundantly used for the worshipers for the God every day (Mitali and Amita, 2015).

The present study focuses on the conversion of the flower waste into the formation of nutrient rich organic manure which is used for the major intention of increasing soil fertility and productivity for proper growth and development of plants. The flowers also shows the insecticidal and fungicidal activities which helpful for the sustainable agriculture. Also, production of the organic manure from flower waste will encourage the crop growth and proper development as well as it will protect from insect and pest. On the point of view, all temples situated in all over India, temple authorities to make organic manure for reduces the pollution of water and soil as well as increases the employment opportunity also. The further studies are in progress which effect will be produced after using the flower wastes as the manure and to see the effects and causes soon. 


\section{Materials and Methods}

2.1 Collection of flower waste and composting materials

The present study was conducted in Centre of Excellence in Plant Biotechnology, Dr. Panjabrao Deshmukh Krishi Vidyapeeth, Akola, Maharashtra, India. Akola is situated at north of Maharashtra state. It is located at $20.7002^{\circ} \mathrm{N}$ latitude and $77.0082^{\circ} \mathrm{E}$ longitude. Flower waste was collected from Shri Gajanan Maharaj Mandir Sahkarnagar, Akola and Main market, Akola, India. The debris like some coconuts, plastics and other worshiping materials other than flower waste was removed manually. In the found materials, marigold shows big in number and subsequently roses, lotus and jasmines were found. Cow dung essential for composting which is collected from the Veterinary College, Akola, Maharashtra, India. Saw dust increases the porosity which is obtained from woods and collected from Tower chock, Akola, Maharashtra, India. Following mentioned Table 1 shows the initial properties on the collected flower waste.

Table 1: Initial properties of the collected flower waste

\begin{tabular}{|l|c|c|c|}
\hline Parameters & Flower waste & Cow dung & Saw dust \\
\hline Moisture content $(\%)$ & 079.05 & 082.07 & 014.25 \\
\hline $\mathrm{pH}$ & 005.40 & 007.00 & 005.90 \\
\hline Electrical conductivity $\left(\mathrm{mS} \mathrm{cm}{ }^{-1}\right)$ & 004.48 & 003.16 & 000.78 \\
\hline Total organic carbon $(\%)$ & 043.77 & 033.24 & 052.60 \\
\hline Total nitrogen $(\%)$ & 002.10 & 001.41 & 000.59 \\
\hline $\left.\mathrm{C} ; \mathrm{N} \mathrm{ratio}^{\prime}\right)$ & 019.80 & 022.30 & 077.30 \\
\hline Total phosphorus $\left(\mathrm{g} \mathrm{kg}^{-1}\right)$ & 003.17 & 002.50 & 001.19 \\
\hline $\mathrm{Na}\left(\mathrm{g} \mathrm{kg}^{-1}\right)$ & 000.86 & 002.38 & 000.63 \\
\hline $\mathrm{K}\left(\mathrm{g} \mathrm{kg}^{-1}\right)$ & 012.87 & 011.10 & 001.30 \\
\hline $\mathrm{Ca}\left(\mathrm{g} \mathrm{kg}^{-1}\right)$ & 006.28 & 008.78 & 002.93 \\
\hline $\mathrm{Cu}\left(\mathrm{mg} \mathrm{kg}^{-1}\right)$ & 047.84 & 033.25 & 015.89 \\
\hline $\mathrm{Zn}\left(\mathrm{mg} \mathrm{kg}^{-1}\right)$ & 130.32 & 175.45 & 006.23 \\
\hline $\mathrm{Mn}\left(\mathrm{mg} \mathrm{kg}^{-1}\right)$ & 096.00 & 257.50 & 055.00 \\
\hline $\mathrm{Fe}\left(\mathrm{g} \mathrm{kg} \mathrm{g}^{-1}\right)$ & 001.84 & 001.78 & 000.42 \\
\hline $\mathrm{Mg}\left(\mathrm{g} \mathrm{kg}^{-1}\right)$ & 002.46 & 005.83 & 001.25 \\
\hline
\end{tabular}

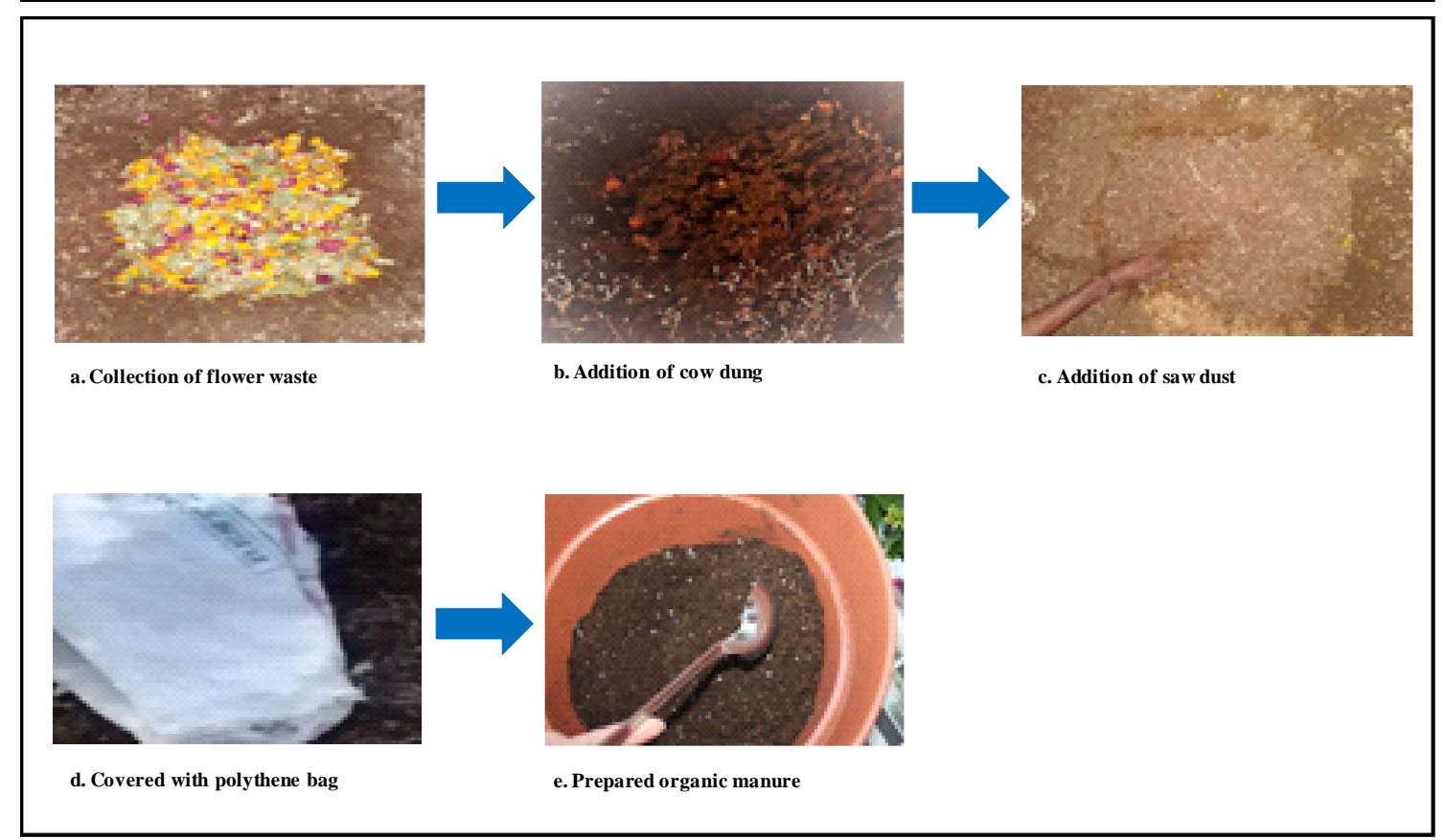

Figure 1: Steps of composting. 


\subsection{Preparation of pit and organic manure}

Same aerated pits of rectangular shaped were prepared. The length of bottom was $60 \mathrm{~cm}$, width $45 \mathrm{~cm}$ and height $75 \mathrm{~cm}$ and the ratio of L/W was kept as 6 with maximum $110 \mathrm{~kg}$ of total weight occupied. After pits completed, thoroughly mixed saw dust and cow dung then simultaneously added flower waste. Steps of composting depicted in the Figure 1.

The all mixture containing flower waste was blend properly. The present investigation was conducted in triplicates and the average value was calculated. For starting, eight days pits were covered with the polythene bags for activation of microbes inside it. The combination of each pit was mentioned in the Table 2. All the pits were mixed down to up in each four days interval manually. The samples were taken for calculating the parameters one a half $\mathrm{kg}$ from last bottom and different locations of samples mixed thoroughly for homogenous mixture obtaining. All procedure was repeated every four days for the first fourty days and then interval of eight days for the next upcoming fourty days. The collected samples from pits were allowed for drying properly and crushed to obtained fine power for correct analysis.

Table 2: Proportion of flower waste, cow dung and saw dust

\begin{tabular}{|c|c|c|c|}
\hline $\begin{array}{c}\text { Name of } \\
\text { pits }\end{array}$ & $\begin{array}{c}\text { Flower } \\
\text { waste }(\mathbf{k g})\end{array}$ & $\begin{array}{c}\text { Cow } \\
\text { dung }(\mathbf{k g})\end{array}$ & $\begin{array}{c}\text { Saw } \\
\text { dust }(\mathbf{k g})\end{array}$ \\
\hline $\mathrm{P}_{0}$ & 50 & - & - \\
\hline $\mathrm{P}_{1}$ & 25 & 20 & 05 \\
\hline $\mathrm{P}_{2}$ & 30 & 15 & 05 \\
\hline $\mathrm{P}_{3}$ & 35 & 10 & 05 \\
\hline $\mathrm{P}_{4}$ & 40 & 05 & 05 \\
\hline
\end{tabular}

\subsection{Determination of physicochemical parameters}

The temperature was measured during the composting interval using the digital thermometer (AVI-CHEM INDUSTRIES Thane, India). Various locations of the pit samples were measured and average temperature was calculated. Moisture content of sample was reported to first 30 days and the moisture content adjusted range between the 55 to $60 \%$ when the pits were dried. For determination of the moisture content of the sample, the gravimetric method was used (BIS, 1895). For calculating the $\mathrm{pH}$ and electrical conductivity, $5 \mathrm{~g}$ of dried samples were diluted by $50 \mathrm{ml}$ distilled water $(1: 10 \mathrm{w} /$ v) and samples were kept on rotary shaker for 120 to $150 \mathrm{~min}$, then allow for settle down, and after that filtered through Whatman filter paper No. 42 (Singh et al., 2016).

By using Kjeldahl method, total nitrogen content were determined. Dividing the factor 1.83 of volatile solids to get calculation of the total organic carbon (Adhikari et al., 2009). The macronutrients like $\mathrm{P}, \mathrm{K}, \mathrm{Na}, \mathrm{Ca}$ and $\mathrm{Mg}$, and the micronutrients, viz., $\mathrm{Fe}, \mathrm{Mn}, \mathrm{Zn}$ and $\mathrm{Cu}$ were determined based on the method of Singh and Kalamdhad (2012). Before the analysis, digested samples were heated by $0.05 \mathrm{~g}$ dry sample with proportion of $5: 1$ of $15 \mathrm{ml}$ of $\mathrm{H}_{2} \mathrm{SO}_{4}$ and $\mathrm{HClO}_{4}$ at $300^{\circ} \mathrm{C}$ for general $120 \mathrm{~min}$. These digested samples were used for calculating the total phosphorous by using stannous chloride method (Dwivedi et al., 2019; Singh and Kalamdhad, 2014). Na and K concentration were determined by using flame photometer (Toplab Company, Navi Mumbai, India). The micro and macronutrients were determined by the Atomic Spectroscopy method.

\subsection{Statistical analysis}

The data was subjected to analysis of variance (ANOVA) and the significance of the difference between the means was determined by $(p<0.05)$ using XSTAT. Values were expressed as means of three replicate determinations \pm standard deviations $(\mathrm{SD})$. The determination of the significant differences between the parameters the analysed the various combinations were the main objectives of the statistical analysis.

\section{Results}

\subsection{Initial characteristics of waste material}

The initial characteristics of the different combinations of flower waste mixture was mentioned in Table 1 . In pit $\mathrm{P}_{0}$, formation of lump was reported due to the more moisture content and also the leachate formation was observed. For reaching the thermophillic phase within one to two days, it covers with polythene bag for increasing the inside temperature and also increase the humidity. Finally, water vapours were seen on the polythene bag. For the activation of the bacterial growth, increased temperature is necessary. For the breakdown of lignin and tannin, water vapours were responsible for fastest degradation (Varma and Kalamdhad, 2014b). In two to three days interval, proper mixing was essential for the provided adequate oxygen which increases the pits temperature. All the parameters of the studied were reported every ten days.

\subsection{Temperature $\left({ }^{\circ} \mathrm{C}\right)$}

For the activation of the microbial growth, temperature is an essential key factor. At the time of composting process, the variation in temperature of each pit depicted in the Figure 2. Cooling and the maturation phase, were attained in each pits during composting, viz., mesophillic phase $\left(40^{\circ} \mathrm{C}\right)$ and thermophillic phase $\left(45^{\circ} \mathrm{C}\right)$, while $\mathrm{P}_{0}$ pits suffered problem for thermophillic phase because of the more moisture content present in the waste and not suitable for microbial growth. $\mathrm{P}_{2}$ and $\mathrm{P}_{3}$ recorded maximum thermophilic phase because of the correct proportion of the cow dung, flower waste and saw dust. For achieving the maximum temperature of the flower waste due to the presence of lower and higher proportion of prepared waste mixture. The highest temperature was observed in $\mathrm{P}_{4}$ and $\mathrm{P}_{3}$ which were 40 and $39^{\circ} \mathrm{C}$, respectively. For the first 10 days, the temperature varies from 50 to $60^{\circ} \mathrm{C}$ to kill all pathogens and it was sanitized the compost (Awasthi et al., 2015). The similar temperature variations were observed by for the different composting waste (Singh and Kalamdhad, 2014; Varma and Kalamdhad, 2014b; Abdullah et al., 2013).

\subsection{Moisture content (\%)}

Moisture content at initial stage of pits $\mathrm{P}_{0}, \mathrm{P}_{1}, \mathrm{P}_{2}, \mathrm{P}_{3}$ and $\mathrm{P}_{4}$ were $79.05 \%, 76.32 \%, 73.67 \%$ and $71.89 \%$. Moisture in $\mathrm{P}_{1}, \mathrm{P}_{2}, \mathrm{P}_{3}$ and $\mathrm{P}_{4}$ decreases respectively by linearly. Figure 3 depicted moisture content, different in each pits. For enhancement the microbial activity cow dung gives the microbial inoculum increases the rate of organic matter degradation. The ratio of cow dung and flower waste were took $\left(\mathrm{P}_{1}\right.$ and $\left.\mathrm{P}_{4}\right)$ more time than $\mathrm{P}_{2}$ and $\mathrm{P}_{3}$. Flower waste and cow dung which indicates that significantly which affects composting and maintained adequate ratio. 


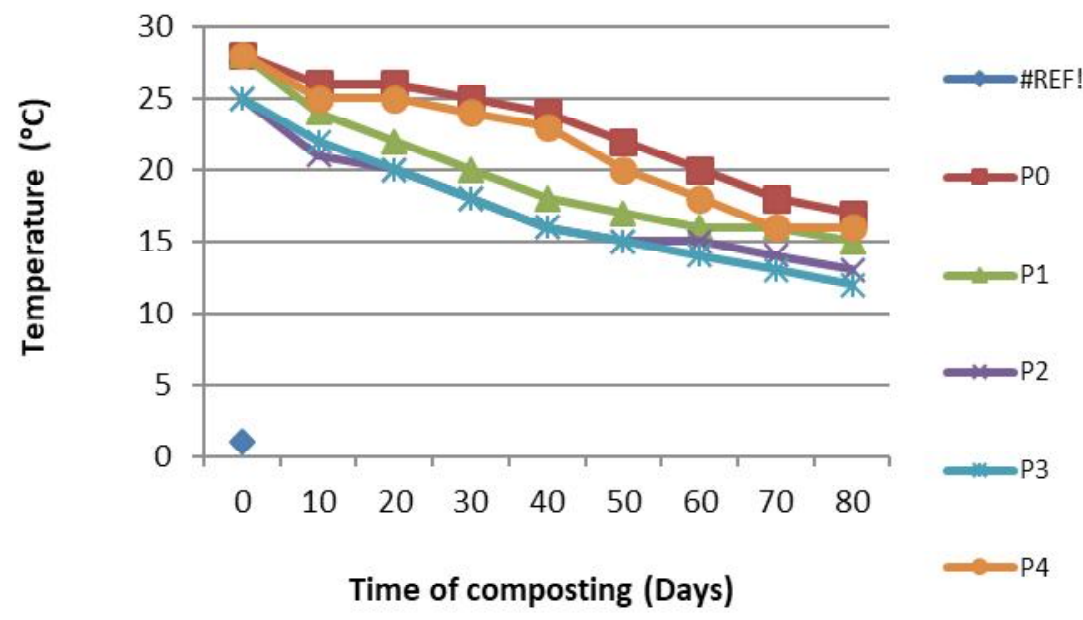

Figure 2: Different temperatures during composting time.

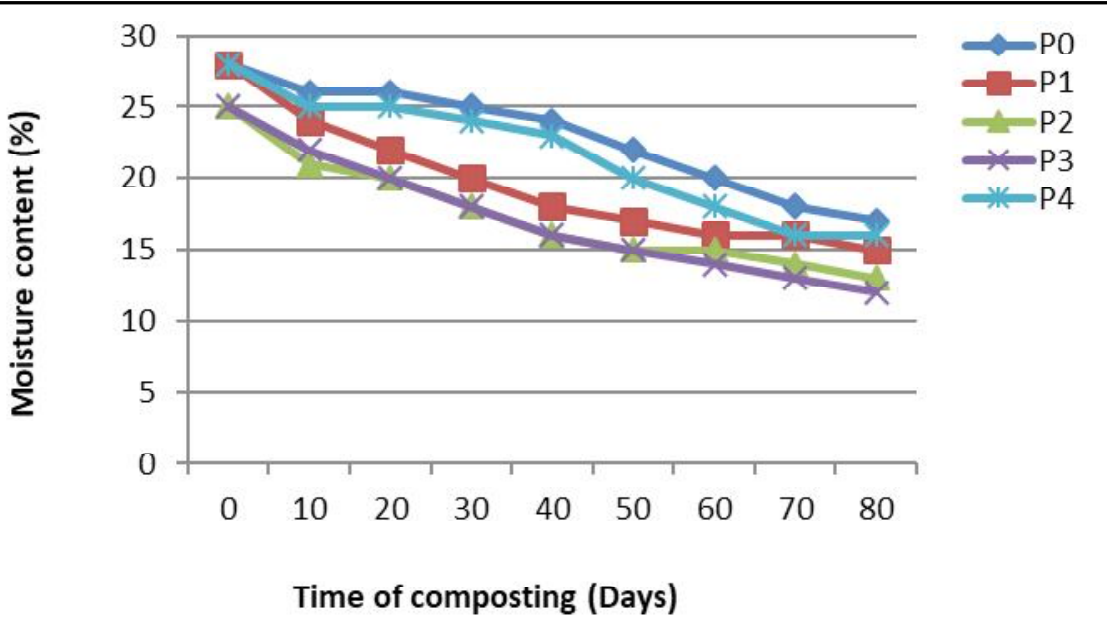

Figure 3: Moisture content in each pit.

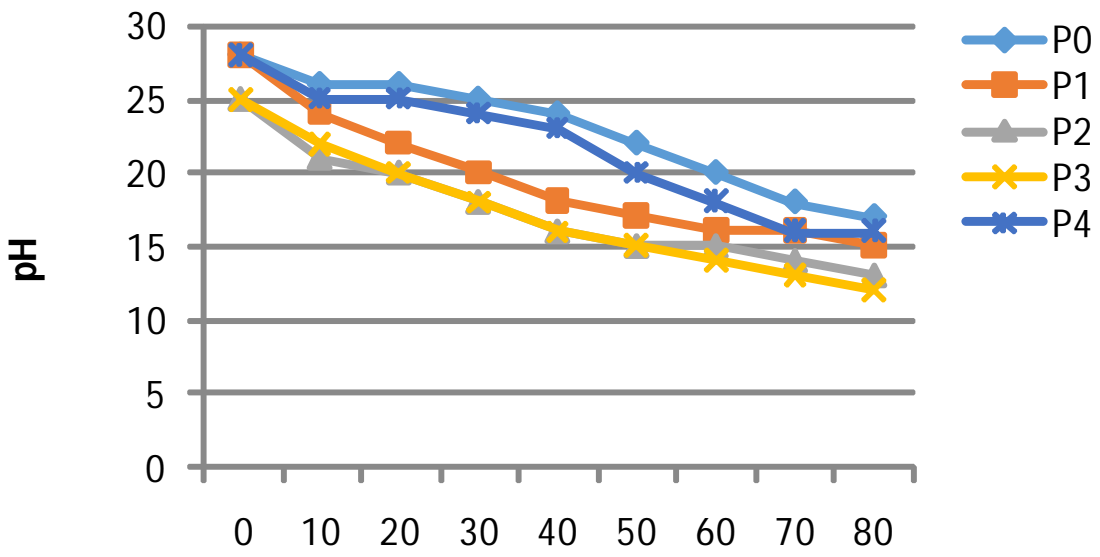

Time of composting (Days)

Figure 4a: Different ranges of $\mathrm{pH}$ during compost time. 


\subsection{Electrical conductivity and $\mathrm{pH}$}

The $\mathrm{pH}$ value was increases for the first 20 days and after 40 days, smaller variation of the $\mathrm{pH}$ value was recorded. 40 days later, $\mathrm{pH}$ of the prepared compost was same at 7.2 to 7.4 in each pit. For regularly mixing, the compost ultimately increases $\mathrm{pH}$ which maintained the oxygen supply to the compost, results to stabilized the aerobic condition (Awasthi et al., 2015). Similar results were observed for composting the organic waste (Kalamdhad and Kazmi 2009; Mena et al., 2003). The pH values at the final stage of the compost were between 6 to 8 , gives the sign of the compost maturity (Varma and Kalamdhad, 2014a). Figure 4a and 4b illustrated the different ranges of $\mathrm{pH}$ and electrical conductivity of the prepared compost.
Salinity of the prepared compost represents electrical conductivity. Range varies from the 0.78 to $6.1 \mathrm{mS} \mathrm{cm}-1$ which provides the suitable growth rate of the plants (Huang et al., 2004). In the initial stages, the electrical conductivity was recorded lower value but which was suitable for composting of the flower waste. At the time of the thermophillic phase, electrical conductivity was increased and after it will stabilize in the cooling phase. In the starting of the thermophillic phases, degradation of the waste took place which produced the mineral salts and resulted in increasing the electrical conductivity. Electrical conductivity gives the volatilization of the salts like ammonium and phosphate (Yadav et al., 2013). Only flower waste not gives the proper degradation of the organic waste due to maximum moisture content and minimum temperature.

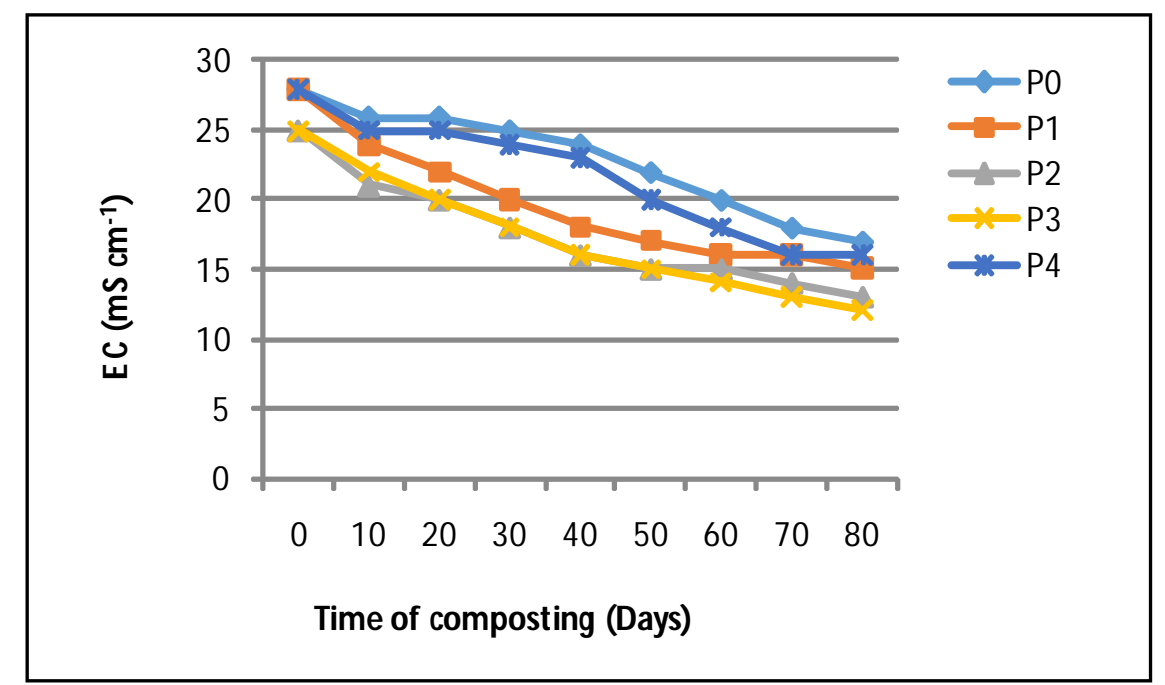

Figure 4b: Electrical conductivity variation during composting time.

\subsection{Total organic carbon (TOC)}

When the carbon concentration changed which indicated the sign of maturity of compost. Figure 5 indicates the total organic carbon and its variation. Total organic carbon was reduced at the time composting process in pits, viz., $\mathrm{P}_{0}, \mathrm{P}_{1}, \mathrm{P}_{2}, \mathrm{P}_{3}$ and $\mathrm{P}_{4}$. As compared to other pits, $\mathrm{P}_{0}$ showed low reduction rate due to the unavailability of cow dung and temperature that is inoculum. $\mathrm{P}_{1}$ gives the easily digest organic waste as compared to the other pits. Because of the thermophillic bacteria availability, the percentage of the total organic carbon was higher in the $\mathrm{P}_{2}$ and $\mathrm{P}_{3}$ which ultimately degrade the proteins and the complex cellulose. Awasthi et al. (2015) and Zhou et al. (2014) reported the similar results in total organic carbon for the organic waste. Mineralization and the compost maturity due the total organic carbon reduced from the organic waste.

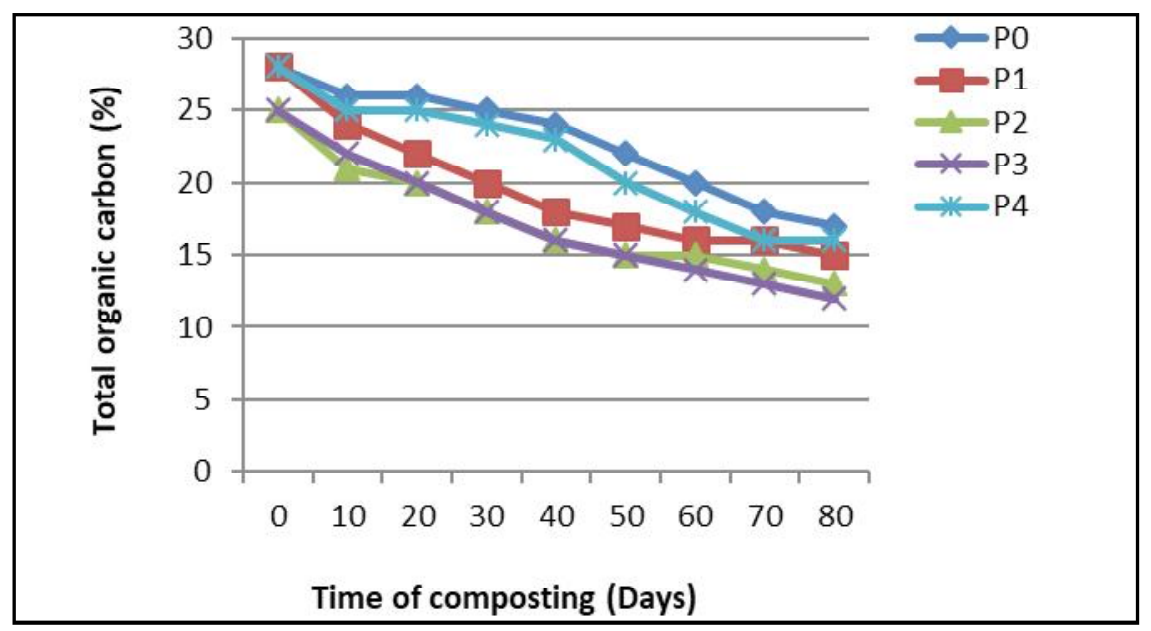

Figure 5: Variation in total organic carbon during composting time. 


\subsection{Macronutrients and micronutrients}

Metabolism of microbes and the proper growth of the plants used macronutrients from the organic matter. Figure 6 indicates the total nitrogen variation in the organic compost. The initial stage concentration of the compost was minimum than the prepared compost in each pits. Jolanun and Towprayoon (2010) recorded the similar results for total nitrogen in the organic matter. Loss of the carbon and organic matter degradation gradually increased the total nitrogen content reported similarly by Garcia et al. (1992).

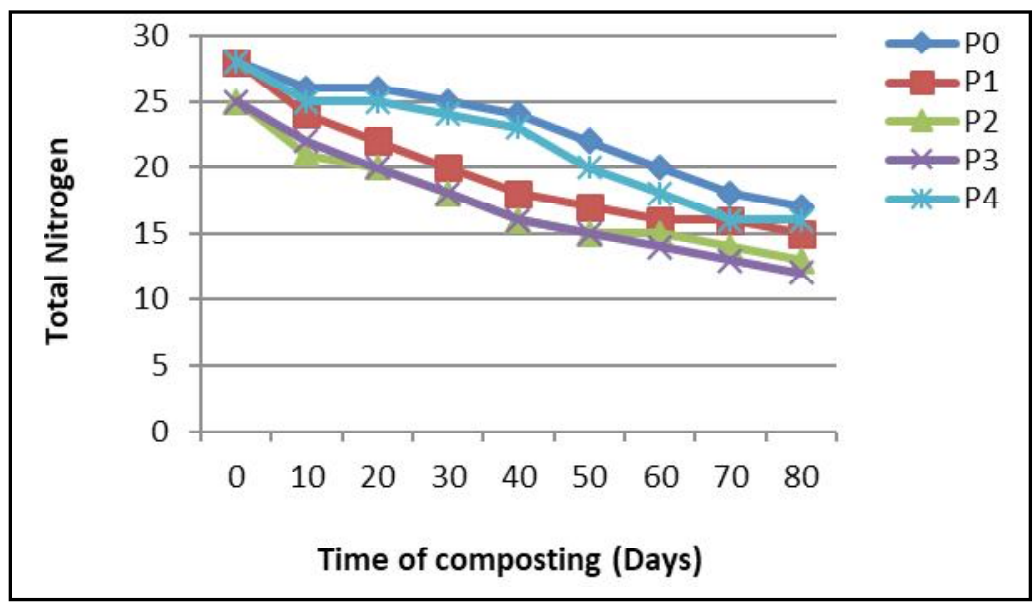

Figure 6: Nitrogen variation in compost waste.

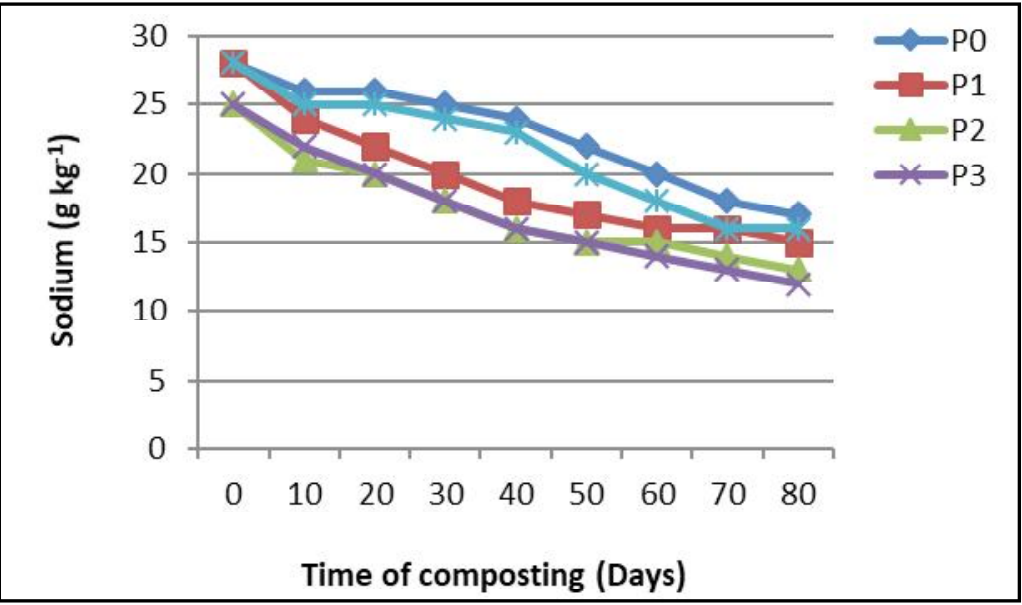

Figure 7: Concentration of sodium in compost.

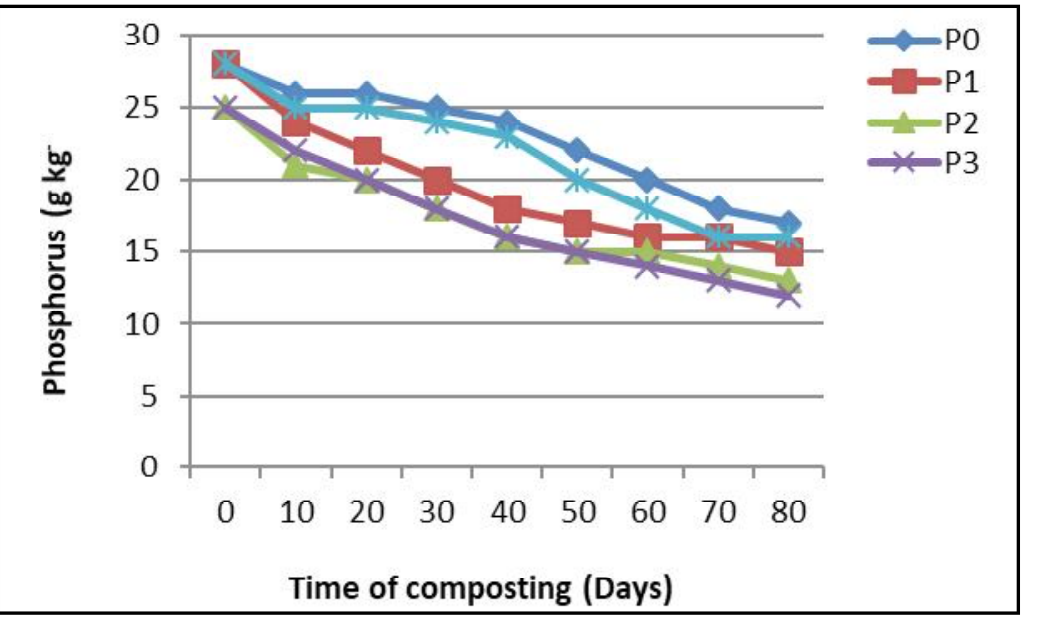

Figure 8: Variation of the phosphorus content in organic matter. 


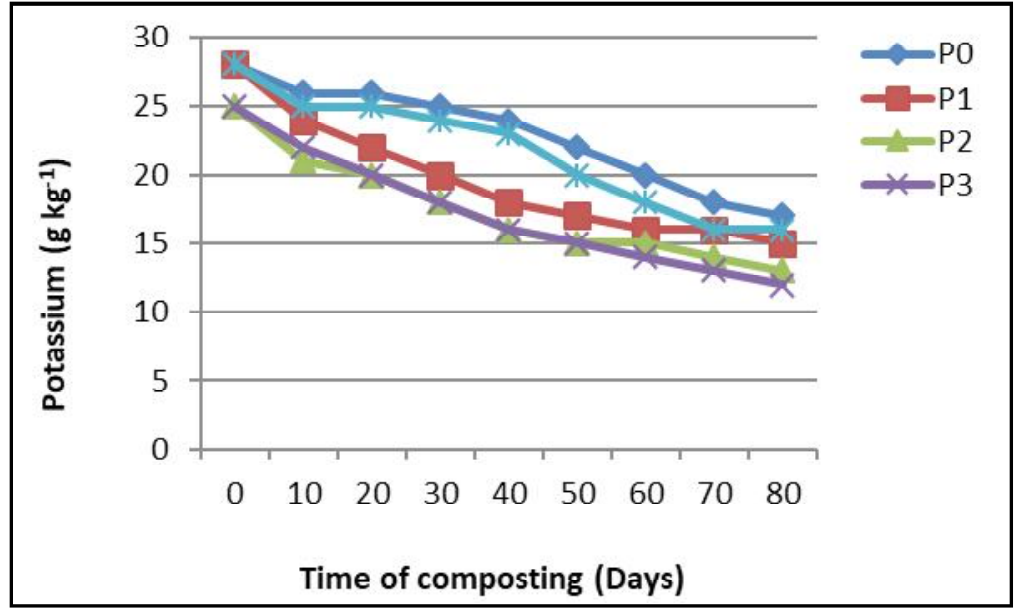

Figure 9: Variation in potassium concentration in organic waste.

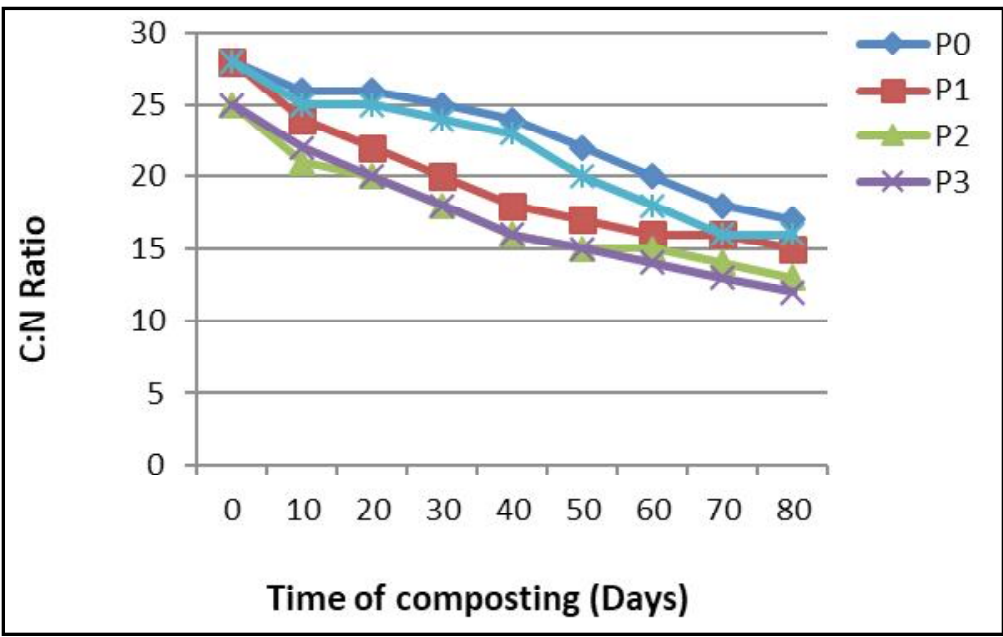

Figure 10: C:N ratio at the time of composting.

Figure 7 illustrated the gradually increasing the concentration of the sodium from the starting to the end of composting process. Within the 80 days of the composting time, concentration of sodium in pits $\mathrm{P}_{0}-\mathrm{P}_{4}$ increased, respectively. During the process of composting, the concentration of all the macronutrients such as $\mathrm{P}$, $\mathrm{K}, \mathrm{Na}, \mathrm{Ca}$, and $\mathrm{Mg}$ gradually increased and which ultimately showed the loss of dry matter because of the organic matter degradation (Bustamante et al., 2009).

The initial and the end of the composting process, the phosphorus contents were gradually increasing $\mathrm{P}_{1}, \mathrm{P}_{2}, \mathrm{P}_{3}$ and $\mathrm{P}_{4}$, respectively. $\mathrm{P} 4$ indicated the maximum phosphorus content followed by $\mathrm{P}_{2}, \mathrm{P}_{1}$, $\mathrm{P}_{0}$ and $\mathrm{P}_{3}$, respectively. Loss of the organic waste matter degradation was due to increase in the concentration of the phosphorus in the prepared compost. Singh et al. (2014) and Varma and Kalamdhad (2014a) reported the similar results for increasing the phosphorus content in the organic matter like vegetable waste and also reported in the water hyacinth. Figure 8 showed the variation of the phosphorus content in the organic matter.

Potassium concentration also increased in the $\mathrm{P}_{1}, \mathrm{P}_{2}, \mathrm{P}_{3}$ and $\mathrm{P}_{4}$ in each pits at the time of end the process of the composting. Potassium concentration shows the high inherent proportion in the flower waste, which indicates the potassium rich in the compost. Mobilization of microbes and potassium assimilation increases the potassium content in each pit (Singh et al., 2012). Figure 9 shows the variation of the potassium concentration in the organic waste.

In the prepared compost, micronutrients present in the very small amounts but micronutrients which helps for the growth and the reproduction of the plant (Wang et al., 2014). For the assimilation of nitrogen and photosynthesis of the plant, manganese is helpful. For the regulation of the growth of the plants, zinc helps for enzyme secretion as well as synthesis of the proteins. Metabolism maintained with the help of copper and iron. Finally, the initial concentration of the micronutrients mentioned in the Table 3. In all the compost, pit micronutrients were observed gradually increasing pattern. Micronutrient present at the end of the composting, the order is $\mathrm{Fe}>\mathrm{Mn}>\mathrm{Zn}>\mathrm{Cu}$.

The highest iron concentration was recorded in the $\mathrm{P}_{0}$ because of the maximum iron content present the flower waste. However, $\mathrm{P}_{1}$ observed the maximum manganese content as compared to other pit. Also, similar $\mathrm{P}_{1}$ recorded the highest magnesium content due to the more quantity of the cow dung present at that proportion. $\mathrm{P}_{2}$ shows the maximum zinc all over other pit because of the zinc 
concentration in the flower waste and the cow dung present in that pit. Flower waste shows the higher concentration of the copper. The present investigation showed the macro and micronutrients rich in the flower waste and which are important for the plant growth and its development. Due to cow dung, microbial activity works more efficiently. In every pit recorded, the micronutrient concentration gradually increasing due to organic matter decomposition and ammonia released from the prepared compost.

Table 3: Initial and final days of the period of composting of macro and micronutrients

\begin{tabular}{|l|c|c|c|c|c|c|}
\hline Elements & Day & Pit 0 & Pit 1 & Pit 2 & Pit 3 & Pit 4 \\
\hline \multirow{2}{*}{ Ca $\left(\mathbf{g ~ k g}^{-1}\right)$} & 0 & 006.22 & 010.30 & 009.02 & 007.84 & 008.56 \\
\cline { 2 - 7 } & 80 & 016.20 & 029.22 & 025.49 & 018.69 & 015.64 \\
\hline \multirow{2}{*}{ Mg (g kg-1) } & 0 & 002.26 & 003.41 & 003.10 & 002.81 & 002.68 \\
\cline { 2 - 7 } & 80 & 006.54 & 006.26 & 005.16 & 006.00 & 005.84 \\
\hline \multirow{2}{*}{ Fe (g kg-1) } & 0 & 000.89 & 001.53 & 001.38 & 001.58 & 001.05 \\
\cline { 2 - 7 } & 80 & 008.42 & 006.50 & 004.57 & 006.56 & 007.59 \\
\hline \multirow{2}{*}{ Mn (mg kg-1) } & 0 & 099.60 & 206.23 & 143.67 & 126.89 & 110.68 \\
\cline { 2 - 7 } & 80 & 125.26 & 245.63 & 171.98 & 170.97 & 152.95 \\
\hline \multirow{2}{*}{$\mathbf{Z n}\left(\mathbf{m g ~ k g}^{-1}\right)$} & 0 & 127.10 & 129.38 & 177.28 & 152.26 & 140.26 \\
\cline { 2 - 7 } & 80 & 163.60 & 176.56 & 204.17 & 192.87 & 173.95 \\
\hline \multirow{2}{*}{ Cu (mg kg-1) } & 0 & 036.20 & 039.24 & 038.23 & 037.29 & 034.25 \\
\cline { 2 - 7 } & 80 & 048.10 & 040.13 & 042.24 & 043.68 & 045.22 \\
\hline
\end{tabular}

\subsection{C:N ratio}

Figure 10 illutritates the C:N ratio variation at the time of the composting process. For the sign of maturity of the prepared compost by checking the $\mathrm{C}: \mathrm{N}$ ratio, nowaday is mostly used parameter (Jiang et al., 2011; Huang et al., 2004). The C:N ratio was varies from 27 to 18 in pit $\mathrm{P}_{0}$ reduced at the last of the composting time. For decrease in the total organic carbon and increase in the total nitrogen at the last of composting ultimately reduces the $\mathrm{C}: \mathrm{N}$ ratio. The $\mathrm{C}: \mathrm{N}$ ratio 26-28 decreased to the 14-16 of $\mathrm{P}_{1}-\mathrm{P}_{4}$ pit at the last of composting time. Microorganisms used the carbon as energy source while for cell structure nitrogen is essential due to that the C:N ratio was reduced (Yadav et al., 2011; Adhikari et al., 2009; Yadav et al., 2009). In the $\mathrm{P}_{2}$, cow dung degrades, $23.8 \% \mathrm{C}$ : $\mathrm{N}$ ratio reduction without reduction of the any carbon content and which ultimately shows the compost maturity. In the $\mathrm{P}_{0}$, cow dung and saw dust absent, shows the less organic carbon reduction and gradually increased in nitrogen contents which simultaneously increased the C:N ratio. The present investigation shows that the cow dung added in the compost which plays a prime role in the total organic carbon reduction and the time of the composting process.

\section{Discussion}

The flower waste plays a key role in the growth and the reproduction of the microorganisms which depends on both physical and chemical properties of the soil, like soil temperature, moisture, $\mathrm{pH}$ and many physicochemical properties. $\mathrm{P}_{4}$ and $\mathrm{P}_{3}$ observed maximum temperature that is 40 and $39^{\circ} \mathrm{C}$, respectively among all pits. During the ten days, temperature varies from the range between 50 to $60^{\circ} \mathrm{C}$ which is responsible for all to kill the pathogen and sanitized the compost (Awasthi et al., 2015). The similar findings were found by Singh et al. (2014); Varma and Kalamdhad (2014b); Abdullah et al. (2013) for the various composting waste. Linearly decrease the moisture content in the $\mathrm{P}_{1}, \mathrm{P}_{2}, \mathrm{P}_{3}$ and $\mathrm{P}_{4}$, respectively. The prepared compost, after 40 days of composting, the $\mathrm{pH}$ was same at 7.2 to 7.4. Continuous mixing the compost during the composting which increases the $\mathrm{pH}$ which ultimately maintains the oxygen supply to stabilized the aerobic condition (Awasthi et al., 2015). Similar results revealed was observed during composting of organic waste Kalamdhad and Kazmi (2009); Mena et al. (2003).

For suitable growth of the plant, electrical conductivity range varies from the 0.78 to $6.1 \mathrm{mS} \mathrm{cm}-1$ (Huang et al., 2004). The percentage of the total organic carbon was higher in the $\mathrm{P}_{2}$ and $\mathrm{P}_{3}$ which ultimately degrade the proteins and the complex cellulose. Awasthi et al. (2015) and Zhou et al. (2014) reported the similar results in total organic carbon for the organic waste. Mineralization and the compost maturity due the total organic carbon reduced from the organic waste. Initial stage of the composting shows the maximum total organic carbon than the prepared compost in each pit. The similar results recorded by Jolanun and Towprayoon (2010). At the time of the composting of the waste, the concentration of all the macronutrients such as $\mathrm{P}, \mathrm{K}, \mathrm{Na}, \mathrm{Ca}$, and $\mathrm{Mg}$ gradually increased, the similar results obtained by Bustamante et al. (2009). Microorganisms used the carbon as energy source while for cell structure, nitrogen is essential due to that the $\mathrm{C}: \mathrm{N}$ ratio was reduced (Yadav et al., 2011; Adhikari et al., 2009; Yadav et al., 2009). 


\section{Conclusion}

The present study concluded that the flower waste composting combination with the saw dust and the cow dung is that agitated pits, as most bulking agent which helps for the prepared compost are fully stabilized at the end of the eighty days composting process. The present study was also observed the leachate clump formation majorly because of the saw dust absent in the flower waste. At the starting, 40 days of process of the composting the higher rate of the organic matter degradation was recorded. Prepared bulking agent in the composting which ultimately helpful for the aerobic condition maintained, finally which reduced formation of the leachate and stabilized the thermophillic phase for longer time.

At the end of composting, macro and micronutrient concentrations which were suitable ranges recorded and ultimately which used for all the agricultural based purpose. Out of all physicochemical analysis, the most appropriate proportion was recorded the pit containing flower waste $30 \mathrm{~kg}$, cow dung $15 \mathrm{~kg}$ and $5 \mathrm{~kg}$ saw dust showed all the essential nutrients which are important for growth and development of the plants.

\section{Acknowledgements}

The authors gratefully acknowledges to the Centre of Excellence in Plant Biotechnology, Post Graduate Institute, Dr. Panjabrao Deshmukh Krishi Vidyapeeth, Akola, Maharashtra, India for providing all necessary facilites for completion of this work.

\section{Conflict of interest}

The authors declare that there is no conflicts of interest relevant to this article.

\section{References}

Abdullah, N.; Chin, N.L.; Mokhtar, M.N. and Taip, F.S. (2013). Effects of bulking agents, load size or starter cultures in kitchen-waste composting. Int. J. Recycl. Org. Waste Agric., 2:1-10.

Adhikari, B.K.; Barrington, S.; Martinez, J. and King, S. (2009). Effectiveness of three bulking agents for food waste composting. Waste Manag., 29:197-203

APHA, (2005). Standard methods for the examination of water and wastewater, 20th edn. American Public Health Association Washington. https://www.standardmethods.org/

Awasthi, M.K.; Pandey, A.K.; Bundela, P.S. and Khan J. (2015). Co-composting of organic fraction of municipal solid waste mixed with different bulking waste: Characterization of physicochemical parameters and microbial enzymatic dynamic. Bioresour. Technol., 182:200207

Bertran, E. and Sort, X. (2004). "Composting winery waste: Sludges and grape stalks", Bioresource Technology, pp:203-208.

BIS, (1982). Methods for analysis of solid wastes (excluding industrial solid wastes). Indian Standard Institution, New Delhi. https:// www.bis.org.in/

Bustamante, M.; Paredes, C.; Morales, J.; Mayoral, A. and Moral, R. (2009) Study of the composting process of winery and distillery wastes using multivariate techniques. Bioresour. Technol., 100:4766-4772.

Dwivedi, A.; Dubey, R.P.K.; Singh, P.K. and Ohri, A. (2019). Scientific management of municipal solid waste in an academic campus: A case study of IIT (BHU). Journal of Materials and Environmental Sciences, 10(10):1-9.
Garcia, C.; Hernandez, T.; Costa, F. and Ayuso, M. (1992). Evaluation of the maturity of municipal waste compost using simple chemical parameters. Commun. Soil Sci. Plant Anal., 23:1501-1512.

Gayatri, B. and Amita, U. (2016). Degradation of flower wastes: A review. International Journal for Scientific Research and Development, 4:83-84.

Huang, G; Wong, J.; Wu, Q. and Nagar, B. (2004). Effect of C/N on composting of pig manure with sawdust. Waste Manag, 24:805-813.

Jiang, T.; Schuchardt, F.; Li, G.; Guo, R. and Zhao, Y. (2011). Effect of C/N ratio, aeration rate and moisture content on ammonia and greenhouse gas emission during the composting. J. Environ. Sci., 23:17541760 .

Jolanun, B. and Towprayoon, S. (2010). Novel bulking agent from clay residue for food waste composting. Bioresour. Technol., 101:4484-4490.

Kalamdhad, A.S. and Kazmi, A. (2009). Effects of turning frequency on compost stability and some chemical characteristics in a rotary drum composter. Chemosphere, 74:1327-1334.

Kumar, V.; Kumari, S. and Kumar, P. (2020). Management and sustainable energy production using flower waste generated from temples. In: Environmental Degradation: Causes and Remediation Strategies, 1:154-165.

Mena, E.; Garrido, A.; Hernandez, T. and Garcia, C. (2003). Bioremediation of sewage sludge by composting. Commun. Soil Sci. Plant Anal., 34:957-971.

Mitali, M. and Amita, U. (2015). Study of flower waste composting to generate organic nutrients. International Journal of Innovative and Emerging Research in Engineering, 2(2):145-147.

Singh, W.R. and Kalamdha, A.S. (2014). Potential for composting of green phumdi biomass of Loktak lake. Ecol. Eng., 67:119-126.

Singh, J. and Kalamdhad, A.S. (2012). Concentration and speciation of heavy metals during water hyacinth composting. Bioresour. Technol., 24:169-179.

Singh, J.; Saxena, R.; Bharti, V. and Singh, A. (2018). The importance waste management to environmental sanitation: A Review. Adv. Biores., 9(2):202-207.

Singh, W.R. and Kalamdhad, A.S. (2016). Transformation of nutrients and heavy metals during vermicomposting of the invasive green weed Salvinia natans using Eisenia fetida. Int. J. Recycl. Org. Waste Agric., pp:1-16.

Suraliwala, F.; Divekar, A. and Gopalkishan, B. (2017). Conversion of Tagetes erecta flower a temple waste to organic manure Proce. Int. Conf. Emerging tool for Sus. Agri., ISBN:978-81-923628-4-7.

Varma, V.S. and Kalamdhad, A. (2014a). Evolution of chemical and biological characterization during thermophilic composting of vegetable waste using rotary drum composter. Int. J. Environ. Sci. Technol., pp: $1-10$.

Varma, V.S. and Kalamdhad, A.S. (2014b). Stability and microbial community analysis during rotary drum composting of vegetable waste. Int. J. Recycl. Org. Waste. Agric., 3:1-9.

Wang, K.; Li, X.; He, C.; Chen, C.L.; Bai, J.; Ren, N. and Wang, J.Y. (2014). Transformation of dissolved organic matters in swine, cow and chicken manures during composting. Bioresour. Technol., 168:222228 .

Yadav, A. and Garg, V.K. (2009). Feasibility of nutrient recovery from industrial sludge by vermicomposting technology. J. Hazard. Mater., 168:262-268. 
Yadav, A.; Gupta, R. and Garg, V.K. (2013). Organic manure production from cow dung and biogas plant slurry by vermicomposting under field conditions. Int. J. Recycl. Org. Waste Agric., 2:21.

Yadav, I.; Singh S.; Juneja, S.K. and Chauhan, S. (2018). Quantification of the Temple Waste of Jaipur city. Rec. Trends in Agri. Food Sci. Forestry, Horti. Aqua, Ani. Sci. Biodive, Eco Sci, Climate Change (AFHABEC2018) ISBN: 978-93-85822-64-3
Yadav, K. D.; Tare, V. and Ahammed, M.M. (2011). Vermicomposting of sourceseparated human faeces by Eisenia fetida: Effect of stocking density on feed consumption rate, growth characteristics and vermicompost production. Waste. Manag., 31:1162-1168.

Zhou, Y.; Selvam, A. and Wong, J.W. (2014). Evaluation of humic substances during co-composting of food waste, sawdust and Chinese medicinal herbal residues. Bioresour. Technol. 168:229-234. 